\title{
Effect of Media Trainer on Electromagnetic Control and Industrial Panel on Learning Outcomes
}

\author{
Adi Ika Rachmawan ${ }^{1, a^{*}}$, Supari Muslim ${ }^{1, b}$, and Bambang Supriato ${ }^{1, c}$ \\ ${ }^{1}$ Department of Technology and Vocational Education, Postgraduate of Surabaya State University, Surabaya, Indonesia \\ a adierachmawan04@gmail.com; b suparimuslim@gmail.com; c bangjosp@yahoo.com; \\ ${ }^{*}$ Corresponding Author \\ Whatsapp number [+6285235891754]
}

How to Cite : Rachmawan, A., I., Muslim, S., Supriato, B. (2019). Effect of Media Trainer on Electromagnetic Control and Industrial Panel on Learning Outcomes. International Journal for Educational and Vocational Studies, 1 (7), 719-723

\section{ARTICLE HISTORY}

Received: 13 July 2019

Revised: 14 August 2019

Accepted: 27 September 2019

\section{KEYWORDS}

Learning Outcomes;

Industrial Panels;

Problem Based Learning;

Electromagnetic Control Trainers;

\section{ABSTRACT}

The purpose of this study is: (1) to determine the quality of the learning medium of electromagnetic control trainers and learning devices, and learning instruments using problem-based learning models; (2) to know the influence of students ' learning outcomes between the learning media of electromagnetic control trainers and industry panels on student learning outcomes. This type of research used was experimental quasi research with a quantitative approach and a Nonequivalent control group design. The learning outcomes in this study were the results of the study of the cognitive sphere, the study of the affective realm, and the results of learning psychomotor realm. Data collection is with test sheets on pretes and postes for cognitive learning outcomes, observation sheets of students learning attitudes for the results of the affective realm and observation sheets for psychomotor realm learning outcomes. The results showed that: (1) The learning medium of electromagnetic control trainers, learning devices, and learning instruments using problem-based learning models received excellent quality results; (2) Learning results of students who learn to use the learning media of the higher electromagnetic control trainer significantly compared to the learning outcomes of students who learn using industrial panel media.

This is an open access article under the CC-BY-SA license.

\section{INTRODUCTION}

Government of the Republic of Indonesia Law on national Education system number 20 year 2003 article 1 paragraph 1 states that education is a conscious and planned effort to create learning atmosphere and learning process so that students Actively develops its own potential to possess religious spiritual strength, self-control, personality, intelligence, noble morality, as well as the necessary skills of himself, society, nation and state. In Indonesia there are two types of high school, namely public high School (SMU) and vocational High School (SMK).

According to government regulation of the Republic of Indonesia No. 17 year 2010 Article 80 paragraph 1, stating that the study of SMK will determine the scope of subjects in each type of field of expertise. Fields of study are adjusted to the types of employment. Vocational education emphasizes students to be able to follow the development of technology and application of technology in accordance with the field taken for SMK graduates to be skilled personnel in the face of the development of science and technology (IPTEK), as well as being able to compete in the workforce.

The quality of education in SMK can be seen from student learning achievement that is the form of maximum learning outcomes. Students' learning outcomes are influenced by two factors, internal factors and external factors. Internal factors are the factors that concern students in the form of learning interests, student response and student motivation, while external factors are factors that include the process of learning which in the form of teaching teachers, models learning, facilities and infrastructure, school environment, and learning Media

One external factor to improve student learning outcomes is learning media and learning models that are appropriate and in accordance with the subject matter being taught (Suhada, 2019). This is in line with Sondang (2015: 9) states that to support the teaching and learning process, media (tools) are needed, while learning media according to Triatna (2009) are various types of 
components in the student environment that can stimulate them to learn. The learning model used in this study is problem based learning. According to Arend (2008: 41) problem based learning is a learning approach that exposes students to real problems with the aim of students being able to compile their own knowledge, foster a high level of thinking, independence of students and increase self-confidence. This is in line with Wijayanto (2009: 15) which states that problem based learning is a learning model that uses existing problems in the real world to train students to think critically and skillfully in solving problems and gain knowledge about important concepts from what is learned.

Electric Motor installation is one of the subjects in the engineering department of Electrical power installations in vocational high school. The subjects of the electric motor installation teach about drawing of electric motor installation series, planning materials of electric motor installation, and application of installation of electric motors, in which the students are required to Analyze image planning, apply installation of electric motors, operate the installation of electric motors based on the planned work system.

Based on observations in the School of Vocational Bhirawa Pare Canda conducted on October 20, 2018 Department of Electrical installation engineering that the curriculum used in SMK Canda Bhirawa Pare divided into 2, namely in class X and class XI used the curriculum 2013, while the class XII used KTSP. Learning Media used in the subjects of electric motor installation in SMK Canda Bhirawa Pare is still using industrial panels to carry out the learning process in the subjects Intalasi plans electric motors. In the results of interviews, students argue that the subjects of the installation of electric motors is one of the lessons that have a moderate level of difficulty, the lack of learning media in the installation subjects of electric motors owned by the school require that students perform the manual installation practicum of electric motors by using industrial panels, so it takes a long time in each work of practicum which resulted in the less effective learning process direct impact on student learning outcomes.

Based on the background explanation above, it is necessary to designed an electromagnetic control trainer that is used as a learning medium that facilitates the students in understanding the basic competence of implementing the installation of various control electric motors. An electromagnetic control Trainer consisting of tools and materials from the mcb 3 phase, mcb 1 phase, contactor, thermal overload relay, push button, timer, indicator light, and jumper cables are packaged into an electromagnetic control trainer. The electromagnetic control trainer is used in the competence of applying various types of electric motor installation series in the DOL series, JOGING series, right-left swivel circuit, manual delta star circuit and automatic star delta circuit. In the learning process also needed a precise learning model in learning the basic competence to apply the installation of various control electric motors. In this study the learning model used was a problem based learning (PBL) learning model. This is because the problem based learning (PBL) learning model is a learning model that uses problems as the core learning, students are designed to think critically and actively in solving a problem using knowledge and essential concepts.

The purpose of this research is: (1) to determine the quality of electromagnetic control trainers and learning devices using problem-based learning models; (2) to know the influence of students ' learning outcomes between the learning media of electromagnetic control trainers and industry panels on student learning outcomes.

\section{METHODS}

This type of research used was experimental quasi research with a quantitative approach. The design of the experimental research used in this study is a Nonequivalent control group design (Cambpell and Stanley, 1970) by applying $2 \times 2$ factorial design. In the $2 \times 2$ factorial experiment Draft, it can be determined the main influence and influence of interactions of all treatment variables

Diagram of the design of quasi own "pretest-postest control group design" 2x2 factorial as shown in Figure 1 below.

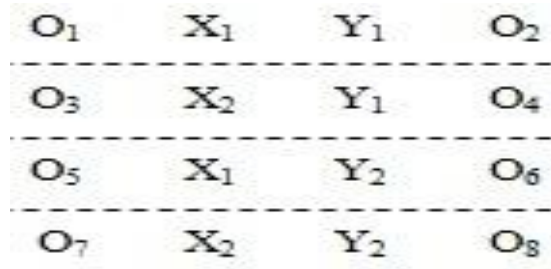

Figure 1. 2x 2 Factorial Design Research plan

This research was conducted on the XI class of the electrical installation Engineering (TITL) program of the even semester 2018-2019 school year in SMK Canda Bhirawa Pare. Research samples are part of the population taken as data sources and can represent the entire population. To determine the sample that will be used requires sampling technique, namely non probability sampling (quota sampling). In this research that is the sample with the quota desired is the students SMK Canda Bhirawa Pare XI-TITL class 4 which amounted to 40 students taught using the learning media TPE (experimental class) and students XI TITL 3 amounting to 40 students the learning media of the PI (control class).

In this study there are 5 research instruments used, namely:(1) sheet validation Media trainer electromagnetic control; (2) learning device validation sheet; (3) test instrument validation sheet of cognitive learning results; (4) test instrument validation sheet of the study result of affective realm; and (5) validation instrument test results of psychomotor. 


\section{RESULTS AND DISCUSSION}

\subsection{Learning Media Quality analysis results, learning tools and instruments}

Before learning instruments are used, a validation test is required. Validation is done by 3 experts, 2 UNESA lecturers and 1 teacher SMK Canda Bhirawa Pare.
Advance validation is intended to get input on expert validator assessment against (1) media trainer electromagnetic controllers; (2) learning devices; (3) test instruments of cognitive learning; (4) test instruments for the study of the affective; and (5) test instruments of the learning of psychomotor realm. The validation result is shown in table 1 below.

Table 1. Learning Media validation results, learning tools and instruments

\begin{tabular}{clcc}
\hline No & \multicolumn{1}{c}{ Learning Tools and Learning instruments } & Rating Results & Category \\
\hline A. & Learning Media Validation & $84 \%$ & \\
\hline 1 & Trainer pengendali elektromagnetik & Excellent \\
\hline B. & Validation of learning devices with TPE media & $94 \%$ & Excellent \\
\hline 1. & Silabus & $94 \%$ & Excellent \\
\hline 2. & RPP & $89 \%$ & Excellent \\
\hline 3. & Jobsheet & $96 \%$ & Excellent \\
\hline C. & Validation of learning result instruments & $95 \%$ & Excellent \\
\hline 1. & Validate grids about cognitive learning outcomes & $96 \%$ & Excellent \\
\hline 2. & Validation of the affective study result observation sheet & $93 \%$ & Excellent \\
\hline 3. & Validation of observation sheet performance test results psychomotor Realm Learning & Average & \\
\hline
\end{tabular}

In the results of the study of the cognitive realm, the results of study of the affective and the results of the psychomotor study of the realm prior to the hypothesis test, carried out test normality and homogeneity in pretes and postes.

\subsection{Cognitive Learning Outcomes}

Test the normality of learning results of cognitive-realm pretes in the experimental class of $0.130>0.05$ and in the control class of $0.271>0.05$, homogeneity test showed the signifkansi $0.142>0.05$. While the test of normality of learning outcomes postes cognitive sphere shows the syndicality of learning outcomes postes the cognitive in experimental classes of $0.132>0.05$ and in the control class of $0.06>0.05$, the test of homogeneity tests showed signifkansi $0.101>0.05$, so it shows that the pretest scores on the experiment class and the control class are normal distribution and the class variant is said to be the same or homogen.

The hypothesis test differentials learning outcomes of students between students who learn by using TPE and students who learn using the PI on the basic competencies implementing the installation of electric motors of various controls after controlling the influence Pretes by conducting the anacova test that appears in table 2 .

Tabel 2. Tests of Between-Subjects Effects

\begin{tabular}{|c|c|c|c|c|c|}
\hline \multicolumn{6}{|c|}{ Dependent Variable: Post-exsperiment_control } \\
\hline Source & Type III Sum of Squares & Df & Mean Square & $\mathrm{F}$ & Sig. \\
\hline Corrected Model & $545.431^{a}$ & 2 & 272.715 & 9.744 & .000 \\
\hline Intercept & 2918.687 & 1 & 2918.687 & 104.287 & .000 \\
\hline Pre-exsperiment_control & 9.240 & 1 & 4.240 & 11.080 & .008 \\
\hline Media & 137.395 & 1 & 137.395 & 4.909 & .030 \\
\hline Error & 2099.031 & 75 & 27.987 & & \\
\hline Total & 515861.500 & 78 & & & \\
\hline Corrected Total & 2644.462 & 77 & & & \\
\hline
\end{tabular}

a. R Squared $=.206$ (Adjusted R Squared $=.185)$

Based on table 2 , the price of $\mathrm{F}_{\text {count }}$ or $\mathrm{F}_{0}$ (media) $=$ 11.080; DF (1.75); With $\mathrm{P}$-value $=0.008<0.05$ which means there is an average difference in the results of cognitive learning between classes of experimentation learning using the media using TPE and the control class that the implementation of learning using the PI media on Basic competencies implement the installation of electric motors of various controls after controlling the influence of pretes. This means learning media has an influence on students cognitive learning outcomes. In the line corrected model, obtained $\mathrm{F}_{0}=9.744$, df $=(2.10)$, and $\mathrm{P}$-value $=0.000<0.05, \mathrm{H}_{0}$ rejected so that the pretes covariat (X) and class (A) simultaneously affect students cognitive learning outcomes. Further testing is carried out with the T-Statistic in the following table 3. 
Tabel 3. Parameter Estimates

\begin{tabular}{lccccccc}
\hline & & & & \multicolumn{2}{c}{$95 \%$ Confidence Interval } \\
\cline { 5 - 8 } Parameter & B & Std. Error & T & Sig. & Lower Bound & Upper Bound \\
\hline Intercept & 75.889 & 8.945 & 8.483 & .000 & 58.068 & .059 \\
\hline Pre-exsperiment_control & .320 & .114 & 2.283 & .040 & .095 & .602 & 11.321 \\
\hline [media=1.00] & 5.961 & 2.690 & 2.216 & .030 &. &. \\
\hline [media=2.00] & $0^{a}$ &. &. &. & &. \\
\hline
\end{tabular}

a. This parameter is set to zero because it is redundant.

The hypothesis test of covariate pretest influence, from table 3 obtained $\mathrm{t}_{0}=2.216, \mathrm{p}$-value $=0.04<0.05, \mathrm{H}_{0}$ rejected, so there is a positive influence pretest on the outcome of learning the cognitive realm of students.

\subsection{Results of Learning affective domains}

The test of the normality of the affective learning results shows the syndicality of the affective study results in the experimental class of $0.924>0.05$ and in the control class of $0.06>0.05$, while a homogeneity test demonstrates the syndicality of the affective learning outcomes In the experimental class of $0.924>0.05$ and in the control class of $0.06>0.05$. So this shows the results of learning the affective students involved in the normal distribution and the students involved in the experimental class and the control class is homogeneous. A hypothesized, learning hypothesis test is using the T-Test Sample Independent test.

Table 4. Independent Sample T-Test study Results Affective

\begin{tabular}{|c|c|c|c|c|c|c|}
\hline \multicolumn{7}{|c|}{ Independent Samples Test } \\
\hline \multicolumn{7}{|c|}{ t-test for Equality of Means } \\
\hline \multirow[b]{2}{*}{$\mathrm{T}$} & \multirow[b]{2}{*}{ Df } & \multirow[b]{2}{*}{ Sig. (2-tailed) } & \multirow[b]{2}{*}{ Mean Difference } & \multirow[b]{2}{*}{ Std. Error Difference } & \multicolumn{2}{|c|}{$95 \%$ Confidence Interval of the Difference } \\
\hline & & & & & Low & Up \\
\hline 9.829 & 78 & .000 & 5.845 & .59470 & 4.66 & 7.02 \\
\hline 9.829 & 77.109 & .000 & 5.845 & .59470 & 4.66 & 7.02 \\
\hline
\end{tabular}

In table 4 indicates that the $\mathrm{T}_{\text {count }}$ score is 9.829 and in the $\mathrm{T}$ distribution table is determined at $=0.05$ with the degree of freedom $(\mathrm{DF})=78$, obtained by 2.021. $\mathrm{H}_{0}$ rejected if $\mathrm{T}_{\text {count }} \geq$ this, based on $\mathrm{T}_{\text {count }}$ and this then obtained the results $(9.829>2.021)$, so that it can be concluded that there are differences of learning outcomes of the students with students who learn using TPE and students who learn using the PI on the basic competence of implementing the installation of electrical motors control.

\subsection{Psychomotor Realm Learning Outcomes}

Test the normality of the psychomotor study showed the syndicality in the experimental class of $0.5>0.05$ and in the control class of $0.74>0.05$. The homogeneity test demonstrates the significance of the learning results of the psychomotor realm in the experimental class and the control class at $0.648>0.05$. So this shows the results of learning the affective students involved in the normal distribution and the students involved in the experimental class and the control class is homogeneous. The hypothesis test is learning psychomotor spheres using the T-Test Sample Independent test.

Table 5 Independent Sample T-Test Test Results of Psychomotor Domains

\begin{tabular}{|c|c|c|c|c|c|c|}
\hline \multicolumn{7}{|c|}{ Independent Samples Test } \\
\hline \multicolumn{7}{|c|}{ t-test for Equality of Means } \\
\hline \multirow[b]{2}{*}{$\mathrm{T}$} & \multirow[b]{2}{*}{ Df } & \multirow[b]{2}{*}{ Sig. (2-tailed) } & \multirow[b]{2}{*}{ Mean Difference } & \multirow[b]{2}{*}{ Std. Error Difference } & \multicolumn{2}{|c|}{$95 \%$ Confidence Interval of the Difference } \\
\hline & & & & & Lower & Upper \\
\hline 16.380 & 78 & .000 & 6.01750 & .36738 & 5.28611 & 6.748 \\
\hline 16.380 & 77.693 & .000 & 6.01750 & .36738 & 5.28606 & 6.748 \\
\hline
\end{tabular}

In table 5 shows that the $\mathrm{T}_{\text {hitung }}$ score is 16.380 and in the $\mathrm{T}$ distribution table is specified in $=0.05$ with degrees of freedom $(\mathrm{DF})=78$, obtainable for 2.021. H0 rejected if $\mathrm{T}_{\text {hitung }} \geq$ this, based on $\mathrm{T}_{\text {hitung }}$ and this then obtained results $(16.380>2.021)$, so that it can be concluded that there are differences of psychomotor learning outcomes between students who learn using TPE and students who learn using the PI on the basic competence of implementing the installation of electrical motors control. 


\section{CONCLUSION}

Based on the discussions that have been done, the conclusion can be withdrawn as follows: (1) Learning medium of electromagnetic control trainers, learning devices, and learning instruments using problem-based learning models Achieve excellent quality results with an average value of $93 \%$, (2) learning outcomes (cognitive, affective and psychomotor) for students studying using the learning medium of electromagnetic control trainers, higher significant compared to the learning outcomes of students using the media panel industry in the basic competence of the installation of electric motors of various controls in SMK Canda Bhirawa Pare.

\section{REFERENCES}

Arends, I, R. (2008). Learning To Teach: Belajar untuk Mengajar. Yogyakarta: Pustaka Belajar.

Campbell, D, T., \& Stanley, J, H. (1970). Experimental and Quasi Experimental Design for Research. Chicago: R.McNally.

Cook, T, D., \& Campbell, D, T. (1979). Quasi-Experimentation Design and Analysis Issues for Field Settings. Houghton: Mifflin.

Muslim, S. (2013). Tes Kinerja (Performance Test) Dalam Bidang Pendidikan Teknologi dan Kejuruan. In Prosiding Seminar Teknik Elektro dan Pendidikan Teknik Elektro (STE 2013) (pp. 11-17). Surabaya: Universitas Negeri Surabaya.

Indrawati, E. M. (2012). Implementasi Pembelajaran Practice Rehearsal Pairs dengan Media Pembelajaran Brosur Gambar Denah Rumah 2 Lantai pada Standar Kompetensi Memasang Instalasi Penerangan Listrik Bangunan Bertingkat di SMK Negeri 3 Surabaya. Universitas Negeri Surabaya.

Maggi, S., \& Sara, S. (2004). Foundation of Problem Based Learning. New York: Open University Press.

Nur, M. (2011). Model Berdasarkan Masalah. Surabaya: Universitas Negeri Surabaya.

Pemerintah Republik Indonesia, 2010. Peraturan Pemerintah Republik Indonesia Nomor 17 Tahun 2010 tentang Pengelolaan dan Penyelenggaraan Pendidikan. Jakarta.

Sondang, M. (2015). Pengembangan Trainer Aplikasi Sistem Digital Sebagai Media Pembelajaran. In M. Mukhrianto, M. Arief, \& D. Triaswira (Eds.), Prosiding Seminar Nasional Pendidikan Teknologi dan Kejuruan (pp. 8-30). Surabaya: Universitas Negeri Surabaya.

Supratiknya, \& Kristiyani, T. (2004). Efektivitas Metode Problem - Based Learning dalam Pembelajaran Mata Kuliah Teori Psikologi Kepribadian II, 33(1), 17-32.

Suprijono, A. (2013). Cooperative Learning. Surabaya: Pustaka Belajar.
Suryanto, A. (2016). Mengoperasikan Sistem Pengendaali Elektromagnetik Pada Siswa Kelas XII TITL1 SMKN 3 Panyabungan Dengan Menggunakan Media Trainer. Jurnal Handayani, 6(1), 154-163. https://doi.org/https://doi.org/10.24114/jh.v6i1.5046

Suyatno. (2009). Menjelajah Pembelajaran Inovatif. Sidoarjo: Masmedia Buana Pustaka.

Syarief, A. (2015). Pengendali Elektromagnetik Kelas XI SMKN 3 Semarang. Journal Edu Elektrika, $4(1), 1-7$.

Suhada, H. (2019). Three In One: Character Building And Academic Achievement With The Making Of Game Religion Multimedia Vocational School. International Journal for Educational and Vocational Studies, 1(6). 627-631.

Trianto. (2007). Model-model Pembelajaran Inovatif. Jakarta: Grasindo.

Trianto. (2009). Mendesain Model Pembelajaran Inovatif Prograsif. Jakarta: Kencana Prenada Media Group.

Undang-Undang Pemerintah Republik Indonesia Nomor 20 Tahun 2003 tentang Standar Nasional Pendidikan Pasal 1 Ayat 1.

Wijayanto, M. (2009). Pengaruh Penerapan Model Problem Based Learning dan Cooperative Learning terhadap Prestasi Belajar Matematika Ditinjau dari Motivasi Belajar Siswa. Universitas Negeri Solo.

Winkel, W, S. (2004). Psikologi Pendidikan dan Evaluasi Belajar. Jakarta: Gramedia Pustaka Utama.

Wirawan, Y. B., \& Wahyudi. (2016). Pengembangan Peraga Trainer Elektromagnetik Sebagai Media Pembelajaran Konsep Kelistrikan Dasar. Jurnal Pendidikan Teknik Mesin, 16(1), 48-52. 